\title{
Coping with Commodification: Hybrid strategies in Asian law firms
}

\author{
Dawn Y. Chow ${ }^{1}$ (D) Lai Si Tsui-Auch ${ }^{2}$
}

Published online: 18 May 2019

(C) The Author(s) 2019

\begin{abstract}
Research has indicated that many organizations are located at complex boundary zones which are guided by differing institutional logics. As varied institutional logics overlap, there may be strains on organizations which are trapped within shared boundaries. To reduce such strains and to respond to institutional logic clash, organizations within different fields tend to resort to hybrid strategies of action. However, despite the plethora of studies, there is still a lack of a coherent body of research that addresses the question of how and why organizations experience institutional complexity differently. In response to calls for research on how particular organizational attributes of firms would matter to the experience of firms in situ, we examine how a particular organizational attribute organizational size - matters, by conducting comparative research on a large versus small Singapore law firm. We thus contribute to the research by showing how hybrid strategies enable organizations to resolve institutional logic clash. Also, we reveal the structural condition underlying the firms' hybrid strategies in response to commodification pressures. Contrary to extant research that suggests otherwise, our findings demonstrate that small, rather than large firms, are in fact better suited to adapt to institutional change, so long as they can carve out a particular niche market for themselves. Additionally, unlike extant research in international business that may have hypothesized a rather large impact of MNCs on a country's competitive landscape, we find that there are limits to the influence that an MNC has, especially on smaller local players.
\end{abstract}

Keywords Institutional change $\cdot$ Organizational response $\cdot$ Social trustee logic $\cdot$ Clientservice logic $\cdot$ Professions

An increasing amount of attention has been paid to how organizations respond to institutional changes associated with the commodification pressures of economic globalization (c.f Yoshikawa, Tsui-Auch, \& McGuire, 2007). Indeed, this is an important topic, as such institutional changes often engender institutional logic clash, with

Dawn Y. Chow

dawnchowyl@ suss.edu.sg

Extended author information available on the last page of the article 
ensuing conflicts over the interpretations of roles, responsibilities, and behavior of firms which are often limited by shared constraints (Murray, 2010; Peng, Ahlstrom, Carraher, $\&$ Shi, 2017). To reduce the potential conflicts, organizations tend to resort to hybrid strategies of action. Some authors focus on logic incommensurability, and analyze domination by incoming, alien logics (Thornton \& Ocasio, 1999). Still others examine logic compatibility, and analyze the coexistence of logics as separated silos (Agrawal \& Henderson, 2002) or logic blending (Rao, Monin, \& Durand, 2003) to reconcile institutional changes internally. Finally, research identifies a fourth approach, distinction, which is when skilled actors reinterpret the meaning of an 'alien' logic to defend their own distinctive institutions (Murray, 2010).

The result of such studies is that we now know that, within the different fields, there are varying organizational responses to institutional logic clash. However, despite the plethora of studies, there is still a lack of a coherent body of research that addresses the question of how and why different organizations experience institutional complexity differently, and hence, how this experience would shape their various responses. We do know that pressures arising from institutional complexity should affect organizations differently, since institutional logics must be filtered by various attributes of the organization (Greenwood, Raynard, Kodeih, Micelotta, \& Lounsbury, 2011). But the how, why, and wherefore of which organizational attributes affect the experience of institutional logic clash have yet to be comprehensively clarified. Research should be extended by examining how particular organizational attributes, for example, attributes such as firm size, would matter to the experience of firms in situ.

In this paper, therefore, we address two research questions. First, what contending institutional logics have law firms encountered due to the liberalization of the legal sector, a necessary consequence of economic globalization? Secondly, how does the organizational size of a firm impact its experience of an institutional logic and affect its subsequent adaptation?

To date, research has tended to focus on the boundary-spanning role of global professional service firms (cf. Faulconbridge \& Muzio, 2016; Jamali, 2010; Tan \& Wang, 2011), and how these global behemoths transplant a predominantly market logic of commodification into their host countries (cf. Faulconbridge \& Muzio, 2016; Tan \& Wang, 2011). Despite this, there has been little in-depth empirical study conducted on how domestic professional service firms themselves resolve their dilemma caused by institutional pressures from economic globalization. A few studies (e.g., Smets, Morris, \& Greenwood, 2012) do examine institutional logic clash within the legal profession, but they are invariably focused on the global law firm, leaving a gap in the literature on responses from domestic firms to economic globalization.

In addition, the preponderance of research is on accountancy firms rather than on other types of professional service firms such as law firms. Some researchers, such as Greenwood and Suddaby (2006), have posited the idea that the legal profession, being a more conservative and protected profession, is somehow immune to the forces of economic globalization. We question this assumption, since the nature of legal work and the profession itself is changing (Flood, 1996) to become far more cross-jurisdictional. We therefore conduct an in-depth field study of law firms in the Singapore context. 
At the same time, research on the effects of market liberalization on professional service firms has so far been limited in terms of geography and service field. East Asian environments, which have encountered the most intense forces of economic globalization, have, ironically, been left out of this research. By conducting our examination in an Asian context, this study expands research settings on the topic and further increases its prominence as an issue of global relevance (Guo, Su, \& Ahlstrom, 2016). Concurrently, this research also responds to calls to study individual industries in Asia as we examine law firms in Singapore (Tan, 2017). For our case, we choose to study the Singapore context because it has an environment similar to many newly industrialized and emerging economies in the region, and is thus a highly suitable context for studying institutional logic penetration. Singapore has a heavy dependence on global finance and trade, an activist state and a strong influence from MNCs. Such environmental conditions make the country highly relevant for identifying contending institutional logics, because the subsequent conflict is particularly acute there owing to the small size of its domestic economy and its economic openness (Tsui-Auch, Yoshikawa, \& Yang, 2015).

Through this research, we make the following contributions. First, we reveal the structural condition underlying the firms' hybrid strategies in response to commodification pressures. Essentially, we examine the differential impact of an intensifying institutional logic on small versus large firms, a topic that the literature is relatively silent on. Conventional wisdom would imply that, due to their economies of scale and abundant resources, institutional logic clash engendered by economic globalization would probably be weathered better by large firms. Yet, interestingly enough, our comparative research suggests that small firms are in fact better suited to adapt to institutional change, so long as they can carve out a particular niche market for themselves.

Second, we contribute to the international business (I.B) literature on the varied responses from local firms to MNCs' entry and their ensuing imported logics. Existing research tends to focus on the intense pressures of MNCs on local firms, and how the latter respond when MNCs enter the market, but this response is dwelt upon in somewhat general terms. For instance, the few I.B papers that use an explicitly institutional logics perspective to an international/global strategy issue do not differentiate between local responses to the influx of logics from foreign actors, instead referring to them as a monolithic bloc with the same sort of hybrid responses of local adaptation once foreign systems have been learned (Chang, 2005). In actual fact, the varying degrees of hybrid strategy warrant further investigation (Ahmadjian \& Okumura, 2006; Chang, 2005). In this paper, therefore, we show the complexity of responses with different local firms of different firm size adopting different strategies.

\section{Literature review}

\section{Institutional logics and institutional theory}

We justify the use of an institutional logic perspective for our study, since an institutional framework helps reveal how contextual forces (e.g., cultural, economic, political, legal) influence change in the nature of organizational practices according to change in 
the institutional environment of an organization (Budhwar, Pereira, Mellahi, \& Singh, 2018; Kostova, Roth, \& Dacin, 2008). Essentially, institutional logics are "symbolic constructions" and "material practices" which influence actors' interpretation of organizational reality and behavior in social situations (Friedland \& Alford, 1991: 248). According to Reay and Hinings (2009), therefore, institutional logics are a valuable tool to unpack the black box of institutional change and examine institutional innovation (Greenwood \& Suddaby, 2006; Wang, Ahlstrom, Nair, \& Hang, 2008) because a shift in the organizational field's dominant logic is fundamental to conceptualizations of change (Thornton \& Ocasio, 2008). Institutional logics have been applied to explain the transformation within various organizational fields - for example, the French cuisine industry (Rao et al., 2003), the commercial microfinance industry (Battilana \& Dorado, 2010), textbook publishing (Thornton \& Ocasio, 1999), recycling programs (Lounsbury, Ventresca, \& Hirsch, 2003), the insurance industry (Schneiberg, 2002), accounting (Covaleski, Dirsmith, \& Rittenberg, 2003), and museums (DiMaggio, 1991; Oakes, Townley, \& Cooper, 1998). Specifically, Rao et al. (2003) looked at how elite French chefs exploited the logic of economy, purity and authenticity in nouvelle cuisine to fashion a new hybrid of cooking styles. Battilana and Dorado (2010), on the other hand, examined how new types of hybrid commercial microfinance organizations are developed and maintained in the face of dueling institutional logics. Besides this, Stark (1996) also explored how the introduction of market-based logics has led to mixed forms of ownership (government and private) in Eastern Europe.

Given that the issue of competitive responses as taken by local firms is, fundamentally, a global business issue in the I.B literature, it seems natural to use an institutional logics perspective to frame the discussion. After all, since economic globalization tends to exacerbate the tensions between incoming and domestic institutional logics, no organization, least of all the local firm, is exempt from the increased strain. However, papers in the I.B field generally do not discuss the impact of institutional logic clash on local firms within the context of increased economic globalization pressures (cf. Dawar \& Frost, 1999; Wu \& Pangarkar, 2006; Yoffie \& Cusumano, 1999). To be sure, the IB literature does dwell upon the entry strategies of MNCs, and more recently, on the response of local firms to these incursions. For example, Kumaraswamy, Mudambi, Saranga, and Tripathy (2012) examine the kinds of catch-up strategies found in the Indian auto components industry; also, Banalieva, Cuervo-Cazurra, and Sarathy (2018) noted that some domestic incumbents will be unable to withstand changes due to increasing market liberalization. However, the explicit focus of such studies is on strategies, and not on conceptualizing institutional logic clash. Yet, since the entry of MNCs into a country changes the "rules of the game," it is only natural to frame the problem of global competition as faced by local firms as an incursion of competing logics.

At the same time, when confronted by competing institutional logics against a backdrop of economic globalization, different organizations are unlikely to experience the same intensity of institutional complexity. This is because attributes frame how organizations perceive and construct the repertoire of responses available to them (Greenwood et al., 2011). For instance, studies have intimated that peripheral players are often disadvantaged by existing arrangements (Ingram, 1998; Kraatz \& Zajac, 1996; Leblebici, Salancik, Copay, \& King, 1991), or that public versus private ownership of the firm in question matters when it comes to assessing the differential impact 
of the logics on the firm (cf. Goodrick and Salancik's 1996 study of public versus private hospitals).

At present, the literature has not clarified a coherent framework illuminating how firms, based on their organizational attributes, would respond differentially to competing institutional logics. For the most part, empirical work on how an organization's attributes matter have been scattered and suggestive at best (Greenwood et al., 2011). This paper does not attempt to resolve this issue by giving the diktat of a one-size-fitsall framework. However, we do attempt to extend theory meaningfully, by looking at how a particular organizational attribute — organizational size - matters. Conventional wisdom dictates that smaller organizations at the periphery are less privileged and have less resources (e.g., Haveman \& Rao, 1997; Hirsch, 1986; Kraatz \& Moore, 2002; Leblebici et al., 1991; Palmer \& Barber, 2001). Such intimations are redolent of Abbott's (1988) analysis of how dominant professions assert themselves over subordinate, less powerful professions, resulting in what DiMaggio (1983) called a "dominance hierarchy." Such studies would therefore hint that larger firms are better placed to weather institutional pressures caused by intruding institutional logics, although todate, only non-conclusive guesses have been hazarded.

As the current theoretical framework is incomplete (Greenwood et al., 2011), we therefore try to extend theory by examining how smaller versus larger firms adapted to institutional change. If, however, smaller players tend to have greater scope for discretion and flexibility in responding to conflicting institutional demands, why should they be the disadvantaged players when an institutional logic intrudes? Should not this issue depend on context? In particular, for professional service firms, would not type of client (and hence market space) be important?

By examining how adaptation was carried out by both types of firms, we would get a better sense of whether it is true that the smaller firms are always disadvantaged when a competing institutional logic intrudes. In that sense, therefore, our paper attempts to situate itself within limited past literature (Ahlstrom, 2010; Ahlstrom, Bruton, \& Zhao, 2013) on the differential impact of institutional logics. To understand adaptation better, however, we first have to understand the available repertoire of hybrid responses available to the firm, as well as the logics prevalent within the institutional context that we are examining. We discuss these topics in the next two subsections. Also, we contribute by arguing that the I.B literature's characterization of strategies as judo or sumo (Yoffie \& Cusumano, 1999) may not be adequate because it is too broad-brush, and the results of our small firm case study demonstrate that, ultimately, firms could respond in a plethora of finely-nuanced ways that enable them to weather commodification pressures better.

\section{Hybrid strategies as organizational responses}

Thornton, Jones, and Kury (2005) noted that when actors within the individual societal sectors come into contact with competing logics, there is space for hybridity and negotiation. The concept of hybridity begins with the premise that organizations do not operate independently of their external environment. Rather, their actions are products of a prevailing, elaborate social context, and they are not de novo, that is, composed entirely anew, but rather, are inter alia, composed through a sometimes complex recombination of existing elements (Battilana \& Lee, 2014; Besharov \& Smith, 2014; Pache \& Santos, 2010). Since multiple logics are represented in the taxonomies of institutions organized by societal sectors 
such as the professions, hybrid strategy would be an appropriate descriptor for the complex boundary work that professional organizations undertake to reconcile competing logics.

Hybrid strategies are broadly conceptualized into four types. The first type is blending, which is when firms use blending mechanisms to reduce the distinction between previously different institutions (Hannan \& Freeman, 1989). The second type is domination (Kuttner, 1997) which is adopted when hybrids are produced as a result of the invasion of one logic by another. A domination strategy is considered to be a type of hybrid strategy because the organizational field was initially rife with multiple logics, but one logic emerges as the dominant one over time, overshadowing but not totally eclipsing the other(s).

What blending and domination strategies share in common is that there is an erosion of boundaries between distinct logics, leading to low maintenance of boundaries at the interface. However, the third type of hybrid strategy - coexistence - enables a separation of distinctive boundaries between resilient logics. For instance, museum curators advocating both conservation and education illustrate a hybrid that equally allows for both professional rhetoric and administrative pragmatism in their place (DiMaggio, 1991; Murray, 2010). In this case, boundaries are stable and no careful coordination between templates of action is required.

The problem with most literature exploring hybrid responses is that they make too easy an assumption that it is possible to combine multiple and often conflicting resources and meanings with little boundary work required (Murray, 2010). As such, Murray (2010) offered a fourth hybrid strategy, distinction, to account for how resilient logics are maintained in productive tension rather than through easy coexistence. The distinction strategy helps account for how skilled actors, who are triggered by tensions between logics, reinterpret or transform the meaning of the resources of an 'alien' logic to defend their own distinctive institutions, thus preserving the essence of their preferred logic. For instance, when commercial realities forced scientists to protect their inventions, scientists changed the traditional meaning of patents and used them as a means of maintaining, and even strengthening, the distinction between the academic and commercial logics (Murray, 2010). The perception, therefore, of the foreign "invading" logic is a negative one and there is thus a high maintenance of boundaries. But the original logic has been adapted to deal with institutional change in a largely ceremonial fashion.

The literature on hybrid strategy offers us a conceptual foundation to identify how law firms in Singapore address competing logics, and to what extent they can maintain the core tenets of their preferred logic while adapting to commodification pressures from economic globalization. The next subsection explores the kinds of institutional logics that are found in the context of the legal profession.

\section{Institutional logics in context}

In the context of the legal profession, what sort of logics does a law firm deal with? In studies of professions, researchers have proposed various logics which influence the organizational field. In general, however, most of these logics come under the broader umbrella of two distinct, overarching logics, that is, professional versus market. The former logic is characterized by professionals relying on abstract knowledge to conduct their practice solely or in partnership with others of the same profession, and largely 
results in professional control over the content, meaning and organization of work (Goodrick \& Reay, 2011). The market logic, on the other hand, is characterized by professional work being encoded in the routines of the firm and subject to the administrative control of managers (Goodrick \& Reay, 2011; Thornton, 2004). For this logic, there is a constant emphasis on performance targets as measured by deliverables such as profits to the firm. So, for example, Smets et al. (2012) proposed a framework to contrast a client-service logic (i.e., market logic) with a fiduciary logic (i.e., professional logic).

In this paper, we use Smet et al.'s (2012) terminology as a heuristic tool to help us better situate the institutional logics confronting the legal sector. We find the concept of a client-service logic depicts well the encroaching logic of economic globalization, with its constant emphasis on marketable deliverables. However, we replace the fiduciary logic with the concept of a "social trustee" logic, a term inspired by Brint's (1994) "social trustee" ideal. This is because the concept of fiduciary logic is narrower in scope. Although it refers to professional responsibility to the broader community, it tends to refer to a legal orientation to act solely in another party's interests for the safekeeping of wealth or assets (Thornton et al., 2005). However, it is generally acknowledged that certain professions, such as the legal profession, serve an important gatekeeping function for society (Hazard \& Dondi, 2004), for example, the practice of law helps articulate consumer rights. Hence, our characterization of the logic as "social trustee" is preferred because it emphasizes the guardianship function of the profession in a broader sense.

Therefore, for our institutional context, we surmise that there exist two competing logics - "social trustee" and "client-service." To elaborate, for the former, overt commercialism is suppressed, and its motivation is drawn from nineteenth-century standards of professionalism when professionals were an elite class of aristocrats who pursued professional occupations out of an altruistic desire to acquire knowledge for knowledge's sake (Brint, 1994; Greenwood \& Suddaby, 2006). Two assumptions predicate the social trustee ideal. The first is that there are asymmetries of power and expertise between professionals and clients since the former possess "exclusive, proprietary knowledge" (Scott, 2008: 223). The second is that the professional will not abuse his/her position of power due to strong, public interest norms.

By contrast, we posit that the client-service logic facing the legal profession resembles other similar market logic concepts in the existing literature, and it is rent based. Thornton et al.'s (2005) corporate logic for accountancy posits that accountants' main purpose is to sell services and generate profits. The market mechanism generally rewards those who can capitalize on their expertise to serve clients' needs. In other words, adequately fulfilling the needs of consumers represents the highest level of consumer welfare where "good ethics makes good economics" (Suddaby \& Greenwood, 2005, p. 48). Law firms' profit-maximizing goals are thus compatible with clients' commercial objectives. In practice, following a client-service logic means that lawyers adopt a highly pragmatic approach to work and provide clients with a more business-savvy, packaged solution.

The literature on the social trustee ideal and client-service logic provides us with a conceptual foundation to characterize competing logics in the legal field in Singapore. In the empirical analysis that follows, we aim at elucidating more comprehensively the distinctive features of each logic, so as to better comprehend the different 
organizational responses law firms will undertake to handle the conflicting institutional logics that they face.

\section{Methods}

In this study, we used a qualitative, multiple-level research design, since the changes in the legal industry involved a hard-to-untangle, complex interplay of factors, such as the changing nature of legal work, governmental policy response and its impact on the various stakeholders. This approach would thus follow Yin (1981) in terms of using case studies for empirical inquiry in situations when the boundaries between phenomenon and context are not clearly evident. At the same time, the qualitative nature of our study enables rich conceptualization that helps with extending theory (López-Duarte, Vidal-Suárez, \& González-Díaz, 2018).

\section{Firm selection}

As is consistent with qualitative research, the selection of our cases was purposive, being based on a theoretical, rather than completely random, sampling, so that our research can focus on incremental theory building (Ahlstrom, Bruton, \& Yeh, 2008; Eisenhardt, 1989; Yin, 2017). We therefore selected two cases that provided a study of contrasts in terms of size, an organizational attribute which, according to our earlier arguments, should affect the kind of firm adaptation. The firms are named as Firm A and Firm B so as to maintain anonymity upon their request. Firm A has been corporatized for more than 60 years and enjoys a reputation of being an established player, and it is also considered to be a large law firm as it has over 100 fee earners (lawyers) and legal support staff combined. Firm B has a relatively short history of about 10 years' incorporation, and is considered to be one of the small and medium sized enterprises (SMEs). We do not report the exact number of years of incorporation in order to maintain anonymity. By looking for cases with enough variations in the hypothesized determinants, we should be able to glean interesting results that could extend emergent theory (Eisenhardt, 1989; Pettigrew, 1990).

\section{Data collection}

Data collection was done via three methods - personal interviews, participant observation and documentary research. All data collection, including the necessary rapport building with potential interviewees, interviews and repeat interviews as well as analysis of data, lasted from 2012 to end 2015. To help crystallize and clarify the initial research ideas, pilot interviews with lawyers were conducted. The second phase involved fieldwork with formal or informal interviews and collection of archival data. Interviewees were selected based on personal contacts, snowball and opportunistic sampling methods. We also conducted interviews with lawyers (partners, associates, and trainees), their clients (e.g., the in-house legal counsel working in commercial banks), business development executives, academics and civil servants who represented a broad spectrum of opinions from Singapore's legal industry. In total, we interviewed 50 professionals from the industry (see Table 1). Personal interviews based 
on semi-structured questionnaires were conducted. Interviews were audio-taped and transcribed verbatim where possible. When respondents declined our requests for audio-taping, we took detailed notes and transcribed the interviews within 24 hours. Getting a wide range of perspectives from different practitioners helps increase the external validity of the study. Internal validity, on the other hand, was improved by repeat interviews with the same interviewees and feedback from respondents. The issue of reliability was addressed by following an interview protocol for the interviews, and by setting strict transcription standards (Schweizer, 2005).

Moreover, the lead author gained permission to do a professional attachment with Firm B for two weeks, during which she observed all work proceedings within the firm, joined training sessions, listened in on conference calls, had informal lunches with the lawyers and gained full access to important documents of the firm. Minute details of day-to-day happenings at the firm were recorded.

To enhance construct validity, data triangulation was undertaken based on multiple sources of data collection (Yin, 2017). Archival data collected and analyzed amounted to over 1,142 pages of legal news (media articles, press releases, commentaries and parliamentary speeches, etc.) that was directly related to the research topic; another 641 pages of articles were collected for background knowledge of the subject.

\section{Data analysis}

Our analysis adopts Eisenhardt's (1989) combined deductive-inductive approach, which employs a number of techniques, including a series of cumulative coding cycles and reflective analytical memo writing (Miles, Huberman, \& Saldana, 2014). As such, data analysis was performed by iterating between literature, data and emerging theory (Strauss \& Corbin, 1990). First, we uploaded the data to a common database for each case. Second, we developed a coding scheme based on the concepts of institutional logics and hybrid strategies. We then identified themes via coding facilitated by the qualitative software NVIVO 10. The reliability of coding was tested on a random sample of about $10 \%$ of all the data. Interrater reliability was above .7, which indicates substantive agreement (Landis \& Koch, 1977). Next we performed a within-case analysis across all interviews and documents, and then did a cross-case analysis by utilizing a matrix technique (Tsui-Auch \& Moellering, 2010). The comparative case analysis led to further iteration between the data and theory to help develop coherent explanations (Shapiro, Ozanne, \& Saatcioglu, 2008).

\section{Case study results}

In terms of firm size of the law firms, as of August 2017, there were 881 firms in Singapore, with 21 being classified as a large firm (above 31 fee earners) and the rest being regarded as SMEs (Law Society, 2017). In 2018, according to the Singapore Ministry of Law website, there were 918 local firms and 126 foreign law firms; separately, there were nine Qualifying Foreign Law Practices (QFLPs). ${ }^{1}$ Headcount

\footnotetext{
${ }^{1}$ Ministry of Law (2017). Statistics. Retrieved from https://www.mlaw.gov.sg.
} 


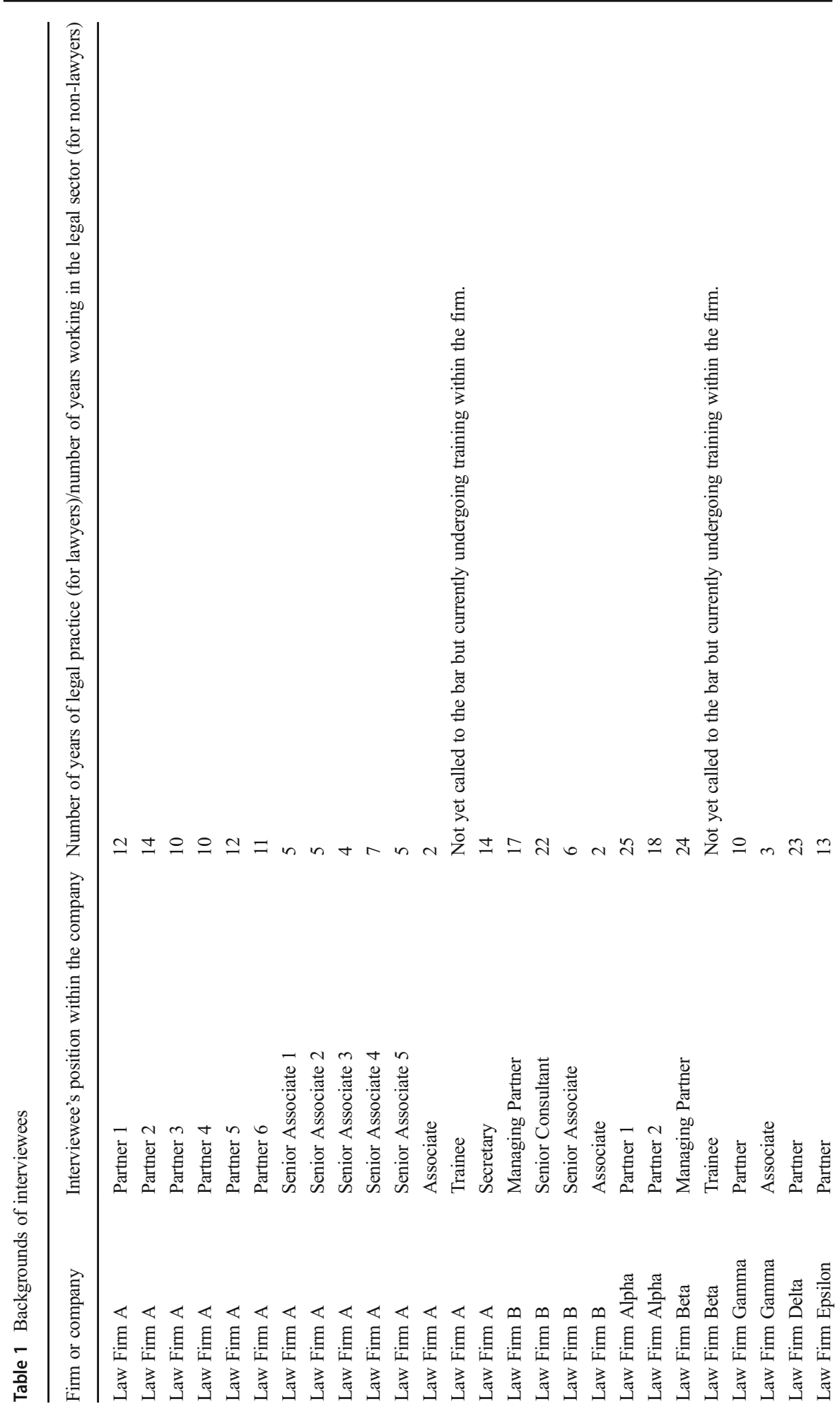




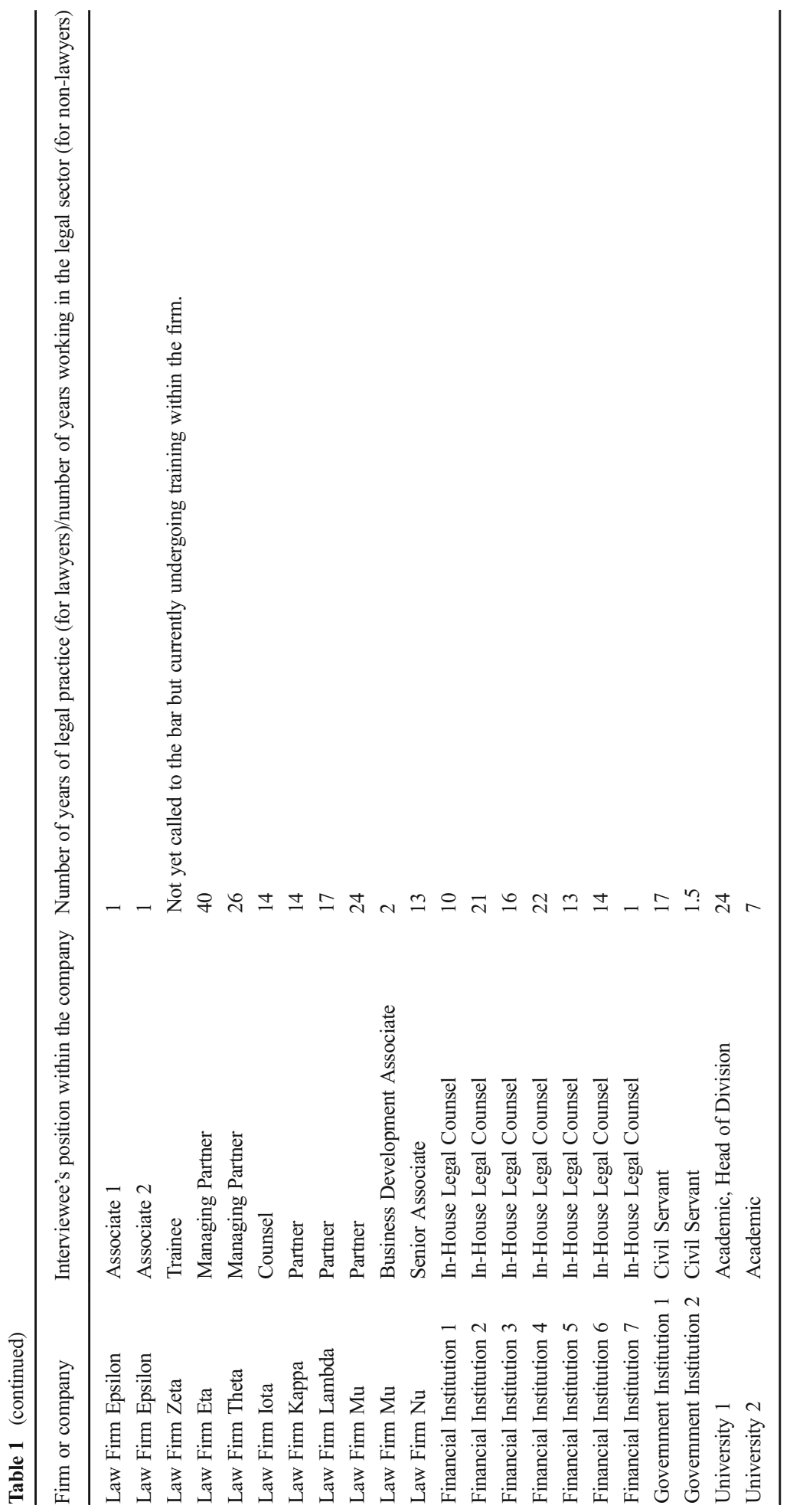


Table 22015 Lawyer headcounts of the QFLPs vis-à-vis the largest local law firms

\begin{tabular}{lllll}
\hline Names of foreign law firms & $\begin{array}{l}\text { Corresponding } \\
\text { global lawyer } \\
\text { headcount }\end{array}$ & $\begin{array}{l}\text { Names of the largest local } \\
\text { law firms }\end{array}$ & $\begin{array}{l}\text { Corresponding lawyer } \\
\text { headcount within } \\
\text { Singapore }\end{array}$ \\
\hline 1 & Allen \& Overy & 2,172 & Allen \& Gledhill & 367 \\
2 & Clifford Chance & 2,495 & Rajah \& Tann & 334 \\
3 & Herbert Smith & 1,868 & WongPartnership & 302 \\
4 & Latham \& Watkins & 2,100 & Drew \& Napier & 275 \\
5 & Norton Rose & 3,461 & Rodyk \& Davidson & 193 \\
6 & White \& Case & 1,878 & Shook Lin \& Bok & 96 \\
7 & Gibson, Dunn \& Crutcher & 1,204 & Lee \& Lee & 94 \\
8 & Jones Day & 2,510 & Khattar Wong & 70 \\
9 & Linklaters & 2,252 & Morgan Lewis Stamford & 75 \\
10 & Sidley Austin & 1,761 & RHT Law Taylor Wessing & 73 \\
\hline
\end{tabular}

Information compiled from The American Lawyer (2015). Global 100, retrieved from http://www. americanlawyer.com, and Asian Legal Business (2015). Asia's Top 50 Largest Law Firms, retrieved from http://www.legalbusinessonline.com/reports/asias-top-50-largest-law-firms-2015

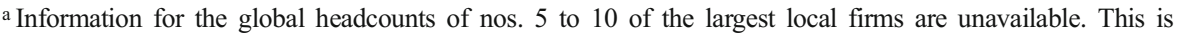
because they do not have much of a multi-jurisdictional presence, if at all. Sometime in 2015, Stamford Law merged with Morgan Lewis Brockius, an international law firm, to become Morgan Lewis Stamford. As such, it cannot properly be called a local law firm by end 2015 . Nonetheless, we report its statistics due to the fact that as of early 2015, it was still considered to be one of the largest local law firms in Singapore with no international headcount. RHT Law company's figures are also reported, because it is a homegrown law firm despite its club membership with Taylor Wessing, a loose network of member firms that are separately registered law practices all over the world. Separately, even if we take into account the global lawyer headcounts of nos. 1 to 4 of the largest local law firms, the figures for each are still in the hundreds, and not significantly higher than their lawyer headcounts within their home country of Singapore. Due to space constraints, we do not report these figures here. They are available upon request

comparisons between the QFLPs and the largest local law firms are presented in Table 2. The local firms were secretive about their revenues earned; however, our respondents noted, off the record, that even the largest local firms' revenues were a tiny fraction of that of the QFLPs. For instance, it would be unreasonable to expect that even a firm such as Rajah and Tann (one of the largest local firms in Singapore), would be able to achieve staggering revenues of USD2.823 billion, which was what Latham and Watkins (a QFLP) earned in 2016 (The American Lawyer, 2017), and is exemplar of the billion dollar revenues that such global law firms can earn. Further, a respondent noted, "[O]f course there are now more than a hundred foreign law firms in Singapore... [Nevertheless] for law firms, there's a fairly clear top tier too... similar to accountancy firms where you have Ernst and Young, Deloitte and Touche, etc." (Partner 1, Law Firm Alpha). Another respondent advised us to "look particularly at those (foreign law firms) that change the nature of the game" (Partner 2, Firm A). Therefore, taking Faulconbridge and Muzio's (2016) approach, we focused more on foreign law firms with multi-jurisdictional capability that would force more international competition into the market (the so-called global law firm MNCs). These game 
changers would be the QFLPs that were awarded licenses to practice Singapore corporate law with no restrictions.

Until the 1990s, Singapore's government had been highly protective of local law firms and held in place practice restrictions for foreign law firms. As a result, the legal field fell behind those of other jurisdictions such as Hong Kong which had already opened its legal sector to entry by foreign firms. Therefore, in 2000, the Singapore state began to liberalize the legal sector amid competitive pressure from the region. Essentially, in that year, the government passed the Legal Profession Act allowing for the formation of Joint Law Ventures (JLVs) between local and foreign law firms, thus permitting a foreign firm to refer its clients to its Singapore law practice in the JLV. Subsequently, the government gave out QFLP licenses in 2008 and 2013. The QFLPs

Table 3 Summary of government policy (institutional changes) in the Singapore legal context

Before 2000
After 2000
Legal system highly protective of local law firms and held in place restrictions for foreign law practices -foreign law firms were not allowed to practice Singapore Law. They could only practice "offshore" (i.e., international) law, their home country law or third country law (Chan, 2009).
1. First wave of liberalization: Legal Profession (Amendment) Act passed by Parliament in January 2000 allowed for the formation of Joint Law Ventures (JLVs) between local and foreign law firms. This scheme allowed a loose coupling between foreign and local firms, giving a foreign firm the leeway to refer its clients to its Singapore law practice in the JLV for matters that required the practice of Singapore Law. In turn, Singapore law firms could also refer work to their foreign counterparts. Nevertheless, without their JLV partner, foreign law firms were still restricted to practicing offshore law in Singapore (Chan, 2009).

2. Second wave of liberalization: In 2008, the government allowed for the establishment of Qualifying Foreign Law Practices (QFLPs). Essentially the QFLP is a foreign law practice which is allowed to practice Singapore Law, but "only through Singapore lawyers who are its partners or associates" (Chan, 2009). The QFLPs are free to practice Singapore Law in all areas of legal practice, except for ring-fenced domestic areas such as litigation, family law, conveyancing and probate law (Ministry of Law, 2013). Six foreign firms were awarded QFLP licenses in the first round (Ministry of Law, 2013). These were the following: Allen \& Overy, Clifford Chance, Herbert Smith, Latham \& Watkins, Norton Rose and White \& Case.

3. Third wave of liberalization: In 2013, the Ministry of Law continued the process of liberalization by awarding QFLP licenses to four foreign law firms namely, Gibson, Dunn \& Crutcher, Jones Day, Linklaters and Sidley Austin (Ministry of Law, 2013).

Information compiled from Chan (2009), retrieved from http://www.aseanlawassociation.org/10 GAdocs/Singapore3.pdf, and the Ministry of Law (2013) press release, retrieved from http://www.mlaw. gov.sg/news/press-releases/award-of-secondround-qflp-licences.html 
were free to practice Singapore Law in all areas of legal practice, except for a couple of ring-fenced domestic areas (Ministry of Law, 2013) (Table 3).

Hitherto these significant changes, law firms had been embedded in a social trustee logic. This had very specific implications for the role of a legal firm, the legal practitioner, the client, as well as sources of legitimacy and basis of strategy, and this was backed up by many quotes from different interviewees across the sample set. For example, partner 1 from Firm A noted that the before and after role of the legal practitioner was quite different:

...[previously] I think a lawyer would, would've seen himself as a [kind of] Jesuit priest...they would deal more with the public at large ... and try to enforce certain norms of what the law says, [and] what the regulations are. ... but with the QFLPs...the competition has pushed us...it has...made us [feel] more concerned about our bottom line...than ... the work for the passion of it.

Such comments were universally corroborated by the other respondents, who noted that smaller law firms would be much less affected by the competition, and thus be relatively free to dwell on their higher social mission. For example, a small firm lawyer insisted that law was "a calling, and not a business, and that "lawyers play[ed] an integral part in framing and shaping society" (Partner, law firm Kappa).

Based on such replies and many more, Table 4 summarizes, in-depth, the dimensions of the institutional logic that predominated before, and after, the institutional changes.

The large organization identified in this study, Firm A, was a large, full-service commercial law firm with much business from transactional and advisory services in

Table 4 Competing logics in the Singapore legal context

\begin{tabular}{|c|c|c|}
\hline Characteristic & Social trustee logic & Client-service logic \\
\hline Role/identity of a legal firm & $\begin{array}{l}\text { A social role/entity to serve } \\
\text { public good. }\end{array}$ & $\begin{array}{l}\text { An economic role/identity with a focus on } \\
\text { extracting maximum rents for the benefit of } \\
\text { the partnership. }\end{array}$ \\
\hline Role of a legal practitioner & $\begin{array}{l}\text { Craft-based artisans with a } \\
\text { focus on esoteric } \\
\text { requirements of the law as } \\
\text { a discipline in itself. }\end{array}$ & $\begin{array}{l}\text { Commercially-oriented advisor with a } \\
\text { boundary spanning role that includes project } \\
\text { management service, business development } \\
\text { and public relations. }\end{array}$ \\
\hline Client role in discourse & $\begin{array}{l}\text { Client is largely dependent } \\
\text { on lawyers. }\end{array}$ & Client dictates the flow of the entire discourse. \\
\hline Sources of legitimacy & $\begin{array}{l}\text { Reputation of key } \\
\text { individuals. }\end{array}$ & Scale and scope of the firm and branding. \\
\hline $\begin{array}{l}\text { Basis of strategy (modus } \\
\text { operandi) }\end{array}$ & $\begin{array}{l}\text { Primary responsibility is to } \\
\text { perpetuate local } \\
\text { governance structures } \\
\text { with little attention to } \\
\text { cross-border elements. }\end{array}$ & $\begin{array}{l}\text { Regionalization: responsibility to clients } \\
\text { stretches across multiple jurisdictions- } \\
\text { market driven, expansion in the form of best } \\
\text { friends' networks, tie-ups with other } \\
\text { firms/regional firms and greenfield strate- } \\
\text { gies. } \\
\text { Attention is given to legal advice with cross } \\
\text { border elements. }\end{array}$ \\
\hline
\end{tabular}


banking, commercial and corporate services, an area which has seen the direct entry of foreign players. But Firm A had not always been a specialized firm. For example, previously it had had generic teams do all the work. Now, however, teams were consolidated into different silos with clear differentiation.

I think the local firms... [now] learn ... how the foreign firms do matter management, file management...and [use] I.T systems that are very good in managing the different work streams or flows and calculating the fees ... and also how they do client networking. The international firms... have a very good client database... from which they can configure everything for all the different clients. Whenever there is new...there is news globally or there are legal updates, these firms actually send out, actively...send automatic emails to these clients to tell them these are updates and to let them know - [this] makes the client feel like they're part of the same team... (Associate 5, Firm A).

And a partner continued,

$[\mathrm{T}]$ here was more and more impetus for us to enhance certain ways we run... operations... that we see practiced, adopted in the international firms. So, a lot of these things that we are doing are more or less the best practices seen throughout the legal world (Partner 3, Firm A).

Based on the in-depth interviews with respondents, Table 5 summarizes the before and after changes in Firm A.

To elaborate, Firm A faced increased business pressures. For example, the Firm felt an increased need to use higher remuneration to attract and retain their staff. Also, the Firm strengthened branding efforts to woo clients, efforts which previously had been conspicuously absent when business was plentiful. In addition, it built alliances with other firms to increase its client pool. Various partners said:

We decided to [raise] the pay of associates by frontloading the bonuses... local firms again have to improve their remuneration practices to be in line with foreign practices.

Local firms have to up [the] PR and marketing skills of their lawyers...[now] they bring in professionals from overseas to train the lawyers on social etiquette, public speaking skills, PR skills, negotiation skills, etc....all these are very new initiatives because of the need to restructure to meet the competition.

I think now there's more of an emphasis in having best friends' relationships [i.e., building strategic alliances] with more, with other independent firms and international firms as well [in order to keep getting business].

The surging domination by a client-service logic was revealed in the following frank remarks: 
Table 5 Internal organizational structure of Firm A before/after institutional changes

\begin{tabular}{ll}
\hline & Before \\
\hline 1. Departments* & $\begin{array}{c}\text { Firm had little differentiation between } \\
\text { departments. }\end{array}$
\end{tabular}

After

2. Marketing and business development

\section{I.T infrastructure and} knowledge management

4. Human resource process changes

5. In-house training of lawyers in the areas of public relations and client-facing skills
Little emphasis placed on these functions since work was plentiful.

State of technology very much in start-up phase; more primitive since there was no need to manage so much information.

Performance assessment targets of individual employees not clear (i.e., not based on revenue generated). Pay tends to be discretionary (e.g., there is a large variable component for year-end bonuses of associates, which can be easily altered).

Virtually non-existent.
Greater emphasis on the specialization of departments; firm began to have different departments and practice groups with designations and functions similar to international law firms. For example, as opposed to one generic team to handle all M\&A work, now there has been a reorganization of the department to focus on separate, growth areas of M\&A work, such as private equity M\&A. The administrative arm of the M\&A department was also spun off to become another department. These measures reflect an increasing refinement of the departments into specialist silos.

Marketing and business development function critical - now, the firm had specialist departments staffed by full-time professionals trained in marketing and business development.

Sophisticated file management system and I.T infrastructure to manage large and continually-expanding precedent database.

Restructure the pay system to be in-line with performance assessment targets. Performance assessment based on numbers (i.e., revenue generated).

Pay of associates increased, pay system restructured by frontloading the bonuses, there is no longer a large discretionary bonus component at the year end.

Emphasis on training lawyers in the areas of social etiquette, public speaking skills, public relations skills, negotiation skills, etc. Professionals brought in from overseas to train the lawyers in these areas.

\footnotetext{
*Here, departments refer to those that carry out actual, business legal services. Marketing and business development are considered support functions of the organization, and they do not have lawyers that advise on clients' legal matters
}

Well, with increasing competition and more pricing pressures and the need to deliver our services at a much higher speed and to deliver them 
more efficiently and effectively, it's only natural for lawyers to feel that law has become much more of a business than a profession. Now, increasingly, clocking time and filling up time sheets have become more and more of a focus for local firms. Lawyers need to work for a targeted number of hours per year. This all goes into performance measurements...something that follows the pattern of the international firms (Partner 1, Firm A).

We advis[e] clients how to go about doing their business so that they won't fall afoul of the law. So that's part of our business, and our business for us is to make money (Partner 2, Firm A).

[We're] [n] ot particularly discerning where these premium clients come from as long as it's good business (laughs) (Partner 3, Firm A).

At the same time, however, respondents noted that large full-service law firms could not solely depend on local clients. Diversifying risks to the rest of the region was an idea that was gaining traction, a point continually reiterated by the lawyers:

The bigger law firms here cannot survive on the local market. You don't have [high profit] margins [here]. It is a very cost conscious market and... and legal services are commoditized already. [The large full-service local law firms]...have moved regionally...[t]hey have not stayed [local]. You can't support a staff...you can't support a structure that size on the floor.

Therefore, the larger local firms tried to counter the onslaught of the international firms by becoming more multi-jurisdictional (i.e., by providing cross-border service). At the same time, this can be explained by the fact that they were trying to operate in the same space (i.e., serve the same type of clients) as the international firms, which necessitated their being able to be a one-stop shop that provided a holistic suite of services for their clients. Archival data showed that there were advantages to providing multijurisdictional service:

There is something about being able to tell a client we can handle everything, including the Singapore aspects. In the scheme of things, that is the biggest win-we can go out there and say 'we can do this, only a third of the market can, two thirds of the market can't' and we're on the good side of that (Interview with Jones Day Partner Dennis Barsky, as cited in Broomhall, 2013).

Triangulation with interviewees from other firms corroborated this:

...to compete with an offshore law firm, become an offshore firm yourself... You [large local law firms] either go regional or you die (Partner 2, Law Firm Alpha).

Firm A was no exception from the other large local firms, for it also tried to expand into other markets such as Malaysia and Vietnam, "[we hoped] to have cross referrals so that the business could grow" (Partner 3, Firm A). However, despite its regionalization 
efforts and other attempts to be more commercial, Firm A's lawyers appeared rather gloomy about the prospects for the firm. This is because they noted that their clients were mainly legal counsel from MNCs or large firms and that these cared a great deal about firm branding. "[Reputation is] definitely a big factor, especially for [our] clients...[s]ay for premium clients for example, premium clients generally would want to know who is the best" (Partner 1, Firm A). However, they felt that ultimately they could not compete

I mean we have retreats and they have retreats, but I know, like, some UK firm, when they go overseas for retreats, everybody stays in Ritz Carlton. Whereas for local firm... you go for a retreat...you stay in, a, a...I don't know, [something] a few shades lower, like I said. This time around the alternative is very formidable, you know! You know, Ritz Carlton and all that (Partner 1, Firm A).

Two drivers may have the same skill sets but the two of them may be driving different cars. One could be a Mercedes and the other one a Proton. Do you get what I mean? It's not just how good your lawyers are, it's how good your platform is? (Partner 2, Firm A).

Triangulation with other lawyers also revealed the fact that premium clients tended to be more selective about their service provider, and based their choice on reputation, plus the fact that firms had to offer them an increased range of services to meet their expanded needs:

Typically we don't outsource (to law firms) unless it's a very complex issue. Expectations of local law firms are A LOT higher now... and there are now so many choices of law firms (In-House Legal Counsel, Financial Institution 1).

However, despite the obvious cleaving to the values of a client-service logic of increased rent-seeking and cost consciousness, Firm A's lawyers still reiterated their responsibility to uphold their duty as officers of the court and advise clients of the regulatory norms in Singapore. At the same time, the reputation of key individuals, a tenet of the social trustee logic, cannot be done away with completely, simply because law is a service industry, and trust is important between the client and the firm. Therefore, Firm A's adherence to certain tenets of the social trustee logic meant that there was no complete collapse of the logic. Quotes from Firm A's lawyers and triangulation with others in the industry revealed this pattern:

From my experience, yes, [there is more of an impetus to please the client] because of competitive pressures, lawyers are driven to engage more and more with clients and to perhaps go out of the way for them... [though] obviously [the fact is] as lawyers you [still] have to advise your client of the risk and discharge your responsibility and duty to them by advising them... [on] what the position in law is (Partner 3, Firm A).

In contrast to Firm A, the intruding client-service logic seems to have left Firm B's core business relatively unscathed. Firm B, the small, boutique law firm for our study, was a 
law firm dealing with corporate and litigation work. It had only 12 legal staff (inclusive of the office manager and secretaries). The firm appears to have been doing well despite the increased competition, "[W]e can barely cope with our [number of] existing clients...we don't think we would want any more." According to Firm B's partners, this is because the firm has found a niche, a different client market from the international law firms. By servicing a niche clientele, Firm B is still able to do interesting, and relatively lucrative work that big law firms are unable to do, due to the fact that the latter have been conflicted out of serving the smaller counterparties due to their work for the big transnationals. So for instance, in the case of a mine acquisition, the firm usually acts for the smaller counterparty on the deal to protect it from being subjected to disadvantages in its negotiation with the big players. Firm B's opposing counsel would be a big law firm acting for the large MNC. Firm B felt that their objective was to help the less resource-rich firms or individuals.

We help the more individual litigants...that might be priced out of the market if they want to go elsewhere. We definitely are priced more competitively than other law firms...the average individual does not have super deep pockets. So in that sense we help the [less resource-rich clients] (Senior Associate, Firm B).

Drawing on the interview data, we noticed that the partners of Firm B were critical of the overt commercialism inherent to a client service logic. Marketing was rather peremptorily dismissed since most of the firm's work came from clients who had sought legal service from the firm since the inception of the firm and from client referrals.

...We came out of the big firms because we wanted to have no politicking, less focus on money, we just wanted to be with our clients and service them...we didn't want to have hours and hours of partners' meetings, paper pushing, etc...(Interview with Managing Partner, Firm B).

In spite of their critique of the client-service logic and the organizational practices that support it, the partners of Firm B drew upon what it deemed to be the key resource implied in this logic-specialist knowledge in niche areas of professional service. Essentially, the partners of Firm B acknowledged that, especially in an environment of increased competition from international firms backed up by years of legal expertise, top quality legal advice was needed by their clients. Therefore, the ethos of the clientservice logic was satisfied by the Firm's judicious hiring of lawyers from top law firms who had specialized knowledge and ability to give quality advice to clients. However, interviewees thought of this as an adaptation, not a fundamental change in the attitude of boutique firms such as Firm B. For example, an In-House Legal Counsel from a financial institution expressed the following sentiment:

In order to 'game' the system...such firms keep doing what they're good at but then they procure talent to reassure clients that they have the expertise. To impress clients? I guess it's a very superficial way but it does help to impress clients. 
With respect to the client pool, we observed that Firm B served clients locally and from a core geographic region, i.e., Indonesia. Firm B tried to follow a regionalization model of innovative expansion to exert influence over geographical and jurisdictional space (Lee \& Ong, 2013). With respect to the regionalization model, which is a basis of strategy for the client-service logic driving the international law firms, there are two elements: (1) scope - the source of legitimacy for the law firm is derived from its scale and scope of services, because these enhance added value in the eyes of clients, and (2) specialization - since the law firm spans multiple jurisdictions, it can lay claim to be an authority as it has got experience doing work everywhere and has built up a rich knowledge base. However, unlike their international counterparts, Firm B's regionalization model is different in some key aspects. It specialized in advising on its home country laws, primarily to reinforce and strengthen its focus on the home market and help less resource-rich clients to survive in the market. At the same time, it reinterpreted the meaning of specialization to mean personalized knowledge tailored to fit the client, deemphasizing scope because it made the deliberate choice to focus on clients from Indonesia, rather than target all other regions. At the same time, Firm B appeared to be a one-man show, in that much of the knowledge base and personal relationships resided in the founder. This was a reinterpretation of the meaning of good service and specialized knowledge:

I've been in Indonesia for 16 years! No Singapore lawyer has half that experience...[I] really know the work...(Interview with Managing Partner, Firm B).

...if any help is needed one just needs to shout out from one's room... [the managing partner] would probably know [the answer] (Interview with Senior Consultant, Firm B).

Firm B took pains to defend its core social trustee logic with respect to its legal and fiduciary duty. For example, the lawyers in the firm believed the purpose of the profession was to help frame legality:

[T] here is some social good in what we do...in the situations where you act against banks... and we do, quite a bit of that kind of work...we act for individuals...so if you get a good judgment on their behalf in that sense you crystallize the law, you can change the banking laws...and affect the judgment for the greater good. This is a very important contribution because Singapore has a pro-banking outlook. If you think about it, if you contribute to developments in the law, whether it be for consumer rights or if it's individual-related in whatever aspect, this can help to crystallize rights more clearly, which obviously is helpful for the individuals...That's where we help. That's where the lawyers can help... in persuading the court to develop the law. This social ethos...is definitely an underlying factor (Senior Associate, Firm B).

Although Firm B admitted that certain international best practices might be useful (for example, "Know Your Client" or K.Y.C processes), overall, respondents noted that they tended to make piecemeal adaptations with regard to organizational practices, and this 
only on a needs-to basis. For instance, compared to the large law firm, Firm B's precedent base was much more scattered and ad hoc, and the overall ethos appeared to be less emphasis on technology, and more on personalized service from the individual lawyer. Additionally, the Firm preferred to let its associates learn by trialand-error. In fact, the founders of the firm preferred to have an open-door policy with their associates should they require any guidance or advice.

[The big firms] are rich in years of experience. For example, if I have a coal mining matter, buying over a coal mine, for instance, they can pull out [many] years' worth of precedents on this and give to their lawyers as a basis for the new matter. But this breeds laziness. They're not reactive. For some big firm meetings, I have gone there and the other side's lawyer (from the big firm) says, I can't do this clause because it's not standard. What does that mean? Just adapt it! Use your head! (interview, managing partner of Firm B).

There was certainly more emphasis on particular personalities within Firm B, as compared to Firm A. For example, dependence on key individuals such as the founder was in fact encouraged, and if any help was needed one just had to 'shout out' from one's room. Firm B's lawyers firmly believed in the personal capitalism of the founder, and they thought that the individual owner-managers should be the ones to control the firm entirely (see also Langlois, 1998), since "firms are managed fairly basically" (Interview with Senior Consultant, Firm B), with little need for the elaborate bureaucracy and organizational structures of the Anglo-American law firms. Resistance against the bureaucracy associated with multiple layers of hierarchy was very apparent:

In terms of (organizational culture)....we are very comfortable....We never learn anything, you don't want to learn anything from the big firms. It's a different temperament here, I think you'll have noticed, from other firms.

Additionally, the partners pointed out the inefficiency of technology and the demerits of a rigid KPI system, which were key support functions of the client-service logic:

At the end of the day, sometimes the traditional systems work best. For example, when I was working in [a large international firm], there could be a partner who was working...20 hours a month? And he charged for exactly 20 billable hours. So his efficiency looked like it was $100 \%$. Whereas I would work for, say, 120 hours a month, and bill like, for $90 \ldots$ no, 100 hours? But it looked like I wasn't $100 \%$ efficient. That's where computers don't capture the full story. It looks like I'm not meeting my KPIs, when in actual fact I am exceeding my billable targets! I'm working to, like, midnight or whatever, and (generating so much more profits) than he is. So after a while, I got fed up...I had to justify myself...what for? (Interview with Managing Partner, Firm B).

Additionally, using NVIVO software, analysis of the data from Firms A and B supported these findings. Firm A's interviews emphasized market realities, cost pressures, pricing demands, service quality, employee retention through pay and the importance of firm branding to an inordinate degree. Clearly, Firm A's key 
Table 6 Frequency of occurrence of key codes associated with the client-service logic

\begin{tabular}{lll}
\hline & Firm A* & Firm B \\
\hline Code name & & 8 \\
Competition for work & 68 & 11 \\
Commercial orientation toward clients & 58 & 6 \\
Commercial orientation toward employees & 30 & 4 \\
Branding and marketing emphasis & 45 & 8 \\
\hline
\end{tabular}

*Frequency is after controlling for differences in total transcript length

preoccupations coalesced around a client-service logic orientation. Even after controlling for size of sample by correcting for the different length of transcript information provided by Firms A and B, the frequency of usage of phrases pertaining to commercial orientation toward clients, commercial orientation toward employees, competition for work and branding and marketing emphasis were still significantly more in Firm A's data. For instance, references associated with the Firm's commercial orientation toward clients appeared at least five times more in Firm A's data, and Firm A's interviewees used branding and marketing references at least eleven times more than Firm B's respondents (Table 6).

By contrast, Table 7 displays the frequency of occurrence of codes that pertain to a social trustee logic. Again, as can be seen, Firm B's references coded for the social trustee logic are also significantly more than Firm A's references. For example, Firm B's interviewees emphasized the social role of the legal firm 19 times more than Firm A, and the social purpose of lawyers five times more than Firm A.

\section{Discussion}

Our case study results showed a contrast in responses - while the large firm trapped itself by completely mimicking the foreign law firms, the small law firm, by contrast,

Table 7 Frequency of occurrence of key codes associated with the social trustee logic

\begin{tabular}{lll}
\hline & Firm A* & Firm B \\
\hline Code name & & 19 \\
Social role of legal firm & .7 & 15 \\
Social purpose of lawyers & 3.1 & 5 \\
Dependency of client on lawyer & 3.13 & 5 \\
Reputation of the partners & 1.0 & 5 \\
\hline
\end{tabular}

*Frequency is after controlling for differences in total transcript length

did much less to counter the onslaught of competition. At the same time, our results highlight the fact that large, established firms have evolved to become more like economic entities rather than keeping their identity as social entities with 
responsibilities to the general public. We discuss the implications of these results in the following section.

\section{Theoretical implications}

Based on our comparative case study, we reveal the role of firm size and type of client in shaping hybrid strategy adoption. Essentially, there are limits to influence that an MNC (and its associated logic) has over local competitors. Firm A, the large firm, had less flexibility in shaping the discourse with its clients and had very little room to maneuver. The domination of a client-service logic over a social trustee logic in its actions is a direct result of its status as an established player with market activities spanning organizational fields influenced by economic globalization. This was because Firm A was constrained by its intended target work and premium paying clientele. Its constraint can be explained by the fact that most of Firm A's corporate and banking clients were in-house counsel from MNCs, and thus they already had a great deal of expert knowledge (meaning that Firm A's natural advantage over them was eroded).

On the other hand, the preferred hybrid strategy for Firm B, the smaller, less established player, was that of distinction. As mentioned previously, distinction is a form of organizational resistance; it is a process of how skilled actors, triggered by tensions between logics, reinterpret or transform the meaning of the resources of an "alien" logic to defend their own distinctive institutions, thus preserving the essence of their preferred logic. In this case, Firm B adapted to the client-service logic by selectively drawing on its key resource (i.e., specialized knowledge) but adapted it to protect its social trustee logic.

Firm B was able to do this, because, as a small, niche market player with a captive clientele, it had more flexibility since it did not directly operate in the crosshairs of economic globalization. Thus it was not constrained by competitive pressures arising from the need for seamless product offerings. In other words, it was fortunate because strategy in the space in which it operated was underdetermined, allowing the firm leeway for more creative interpretation (Murray, 2010). This finding is also consistent with the theory that smaller players tend to have greater scope for discretion and flexibility in responding to conflicting institutional demands (D'Aunno, Succi, \& Alexander, 2000; Greenwood et al., 2011).

Moreover, Firm B had a niche to serve private individuals (i.e., to do non-listed company work for venture capitalists and private owners of mines). These private individuals did not have to answer to any parent company when they chose their legal service provider. As a result, Firm B could retain its many loyal clients. Essentially, it operated in a market niche different from that of the large and international law firms. Although competition eventually would affect Firm B to a certain degree once the larger local firms are forced to move downstream and take the smaller, less lucrative deals, till then Firm B would be relatively insulated. Also, it was a small set-up and did not require much resource to sustain itself. As such, it did not face overt threats to its survival, and the incursion of an alien logic was merely encroachment but not a bid for total control. A combination of these factors means that Firm B had even more tractability in its reinterpretation of the client-service logic and this enabled it to adhere to its core (social trustee) logic. 
Furthermore, Firm B had a priori legitimacy capital (Pache \& Santos, 2010) in the sense that the market accepted the type of work it was doing and the segment it targeted. Some segments of the market, in particular, private individuals conducting business for themselves needed lawyers who had personalized knowledge of their character and nature. Therefore, Firm B was freer to resist the dominant template in the field and adopt an alternative approach in hybridization, hence defending its core logic with great ease. However, Firm A, a large, central player (in terms of its size and reputation) suffered from a disadvantage because, despite its reputation within the Singapore market, in terms of syndicated lending and other sophisticated financial products, it was not an originator of scripts. This was actually the preserve of the Anglo-American law firms, which had created such products in the 1980s (Smets et al., 2012) and these firms possessed superior experience in structuring agreements on such matters. Therefore, Firm A, despite its reputation for good legal advice within the Singapore market, had a legitimacy deficit vis-à-vis its international competitors, and so it was more constrained to demonstrate its fit (Pache \& Santos, 2010) with predominant practices by overcompensating. In fact, interviewees noted that, for large Singapore law firms such as Firm A to compete with the offshore firms, they had to become offshore firms themselves. Thus a domination of the client-service logic prevailed in Firm A, rendering the maintenance of core professional values to be an uphill battle.

The fact that the small firm in this study seems to have weathered institutional change better sounds like a counterintuitive conclusion. However, when viewed in the context of the type of client and market space that it sought to serve, this finding may not be so surprising, in that MNCs, given their behemoth sizes, cannot and would not find it at all lucrative to serve such niches. Small firms, therefore, need not get into the trap of merely mimicking MNCs and playing catch-up like the large local firms. Instead they can craft an appropriate strategy of their own to survive, and, ironically, thrive. Beyond the legal field, we note that a similar dynamic has been at work within the Singapore academic field. Evidently, there are conflicting pressures within academia, that is, the duty to publish-or-perish versus teach undergraduates and postgraduates (Rawat \& Meena, 2014). Yet, small, niche universities (i.e., the Singapore University of Social Sciences and the Singapore Institute of Technology) that focus more on vocational training and workforce upgrading rather than on research are still thriving, as they are able to adapt to institutional change by serving a particular niche market.

In summary, for the professional service firm, the type of hybrid strategy used ultimately depends on the type of client. Indeed, the type of client a firm has is not isolated from the factors of firm size and reputation. As the lawyers interviewed repeatedly reiterated, size and reputation helps the firm in getting the so-called "premium" clients. Because they are small and less reputable, smaller firms have less competitive ability to snatch such customers, and so they focus on other type of clientele. Therefore, we surmise that the framework on organizational attributes that influence hybrid strategy, as proffered by Greenwood et al. (2011), is incomplete. For professional service firms, type of client is an important influencer of firm response. As a direct result of the clientele it served, the large firm in our case study caved in to institutional pressures and pursued a domination strategy by restructuring its practices so that it could catch up with the international law firms. By contrast, the small and less established player in our study displayed a piecemeal adoption of international firm practices such as a focus on specialized knowledge, and it reinterpreted the meaning of 
a regionalization model. Overall, the successful adaptation of the small firm is testimony to the fact that there are limits to an MNC's influence.

In terms of our contribution to I.B research, we draw links between firm size and the nature of competitive response. Wu and Pangarkar (2006) asserted that larger firms tend to participate in contender or extender strategies (i.e., take on global giants by moving into the same market, or even geographic, space as them). However, this very proactive fighting strategy may not always be appropriate-when firm size was increased Wu and Pangarkar (2006) found a dip in performance. The implication, from our case study of Firm A as well as the literature, is that big firms tend to think they should fight. From interviews with Firm A's lawyers, Firm A believed its competitive assets such as legal know-how and precedent base were transferable to other countries, and as such, it tried to proactively expand to other countries such as Vietnam and Malaysia, hoping that incremental benefits such as scale economies and an enhanced brand presence would materialize (these features are exemplar of the extender strategy, c.f. Wu \& Pangarkar, 2006: 298). Nonetheless, this strategy of countering the international firms in an alternative geographic sphere failed miserably - the international firms had deep pockets to fund such expansions, but Firm A had not. Also, as one of Firm A's partners also remarked, they later found that such aggressive strategies were not worthwhile, since the outlay was considerable but by contrast the payoff was low. Therefore, theoretically, while its legal expertise was transferable abroad, Firm A suffered from the liability of newness (Wu \& Pangarkar, 2006), as well as the fact that control within its home market was also being eroded. Rather than morphing into another offshore firm like the international law firms, we suggest that Firm A, the traditional, large-scale firm, would have done better if it had found a way to 'think smaller' and 'more nimbly' (Blume, 2010: 89). Comparing the extent of changes between both Firms A and B, it is clear that the large firm in our study engaged in a relentless pace of hybridization that was aimed at a wholesale revamp of its practices to resemble that of the international firms'. However, the pace of change within Firm B seemed almost languid by contrast. Decoupling was very deliberate and nuanced, and made to suit the Firm's purposes and needs, much to its subsequent success. Other than that, changes in Firm B were minimal, and the firm did nothing at all to change its core ethos.

Finally, we contribute to the existing theory on institutional logics. In the existing research, there lacks a contrast in dimensions embedded in the social trustee ideal and the client-service logic. Our findings, however, clarify these dimensions, namely, the role/identity of a legal firm, the role of a legal practitioner, the client role in discourse, sources of legitimacy, and the basis of strategy (modus operandi) (refer to Table 4).

We find that, with the penetration of the client-service logic in the Singapore legal field, large, established firms have evolved in orientation to focus greatly on extracting maximum rents for the benefit of the partnership. These law firms have aligned their goals largely with clients' profit-maximizing goals. The empowered client dictates the flow of the entire client-firm discourse and thus the role of the legal practitioner has changed. Lawyers are no longer craft-based artisans, focusing on the esoteric requirements of the law as a discipline in itself. Instead, they are expected to play a boundaryspanning role. The client now expects to get "more for less,' not just in terms of increasingly sophisticated legal advice, but also in getting lawyers to interface their technical skillset with other facilities such as project management and good public relations. In Firm A, therefore, legitimacy is derived from its brand, scale and scope of 
services. This is consistent with the literature which indicates that for other professions such as accountancy, legitimacy is determined by the size of the firm, the range of services offered, continual status enhancement of the firm through growth by mergers and acquisitions and increasing differentiation of client services (Jones, 1995; Previts, 1985; Thornton et al., 2005). Nevertheless, with regard to the social trustee logic that Firm B was able to defend, a legal firm can keep its social entity, serving the public good rather than being a purely economic entity. Overt commercialism is deemphasized, and lawyers are trained professionals and craft-based artisans, guiding clients over the discourse. Legitimacy for law firms is often derived from the reputation of key individuals (e.g., the managing partner). Expert knowledge and business relationships reside in these few individuals, without whom the firm could not survive.

Our results reveal, therefore, that prior to the liberalization of the legal sector, a lack of competition for work had allowed the social trustee logic to flourish. Now, however, economic globalization had led to Firm A being more intensely confronted by a clientservice logic. Overall, for Firm A, while we argue for the centrality of a client-service logic, we do not see a complete collapse of the social trustee logic. Instead, we contend that the influence of each logic manifests as a matter of degree. We therefore argue that there is no one-way shift from the adoption of a social trustee logic towards that of a client-service logic, unlike how Thornton and Ocasio (1999) argue for a shift from an editorial logic to a market logic in the publishing industry. Rather, the influence of dual logics on organizations can be conceived of in terms of degree, and they are not mutually exclusive. Essentially, law firms, like audit firms, are able to reconcile both market and professional pressures through hybrid strategy (Greenwood et al., 2011; Greenwood \& Suddaby, 2006).

\section{Limitations and future research}

This study, like many others, has certain limitations, but we believe it can provide a basis upon which to conduct future research. As the study is based on only two law firms in Singapore, the generalizability of the explanation remains to be assessed via studies of more cases. Nevertheless, the focus on a small sample in a single country was necessary to explore the instantiation of logics within-organizations, and, concurrently, the type of hybrid strategies adopted to resolve such a dilemma.

We note that, after 17 years since the liberalization of sector, it does not appear that domination has become the default strategy, or that one particular institutional logic must win out over another. This finding is consistent with research that reasons that firms can and do exercise social agency to counter the domination of an encroaching logic, by outwardly playing by the rules but still keeping their social trustee ethos intact. Nevertheless, an alternative explanation could be that firms in this context still have the luxury of agentic choice because the liberalization of the legal sector has been more measured. It could be that law firms in economies with a higher degree of liberalization might face a domination by the client-service logic and can therefore only exercise limited agentic choice. Future studies could focus on this. Our analysis provides a basis on which to conduct single-country case studies and cross-national comparative studies in the legal field. Indeed, more research on the topic of economic globalization, and how this impacts professional service firms, is sorely needed, especially since firms situated in newly industrialized or emerging economies are 
increasingly competing against MNCs within their home markets (Young, Tsai, Wang, Liu, \& Ahlstrom, 2014).

Our analysis is limited to the firm and institutional levels. There is a growing recognition that organizations are not reified wholes but that multiple logics, and hence core value orientations, could be instantiated within organizations (Besharov \& Smith, 2014; Kraatz \& Block, 2008) and interpreted differently by different members within an organization. An intra-firm analysis might map out more clearly the changes in the ethos of a logic over time and the existence of intra-organizational conflicts wherein recurrent bouts of "legitimacy politics" occur (Ocasio \& Kim, 1999; Stryker, 2000). At the same time, given that individual and organizational actors have some hand in shaping and changing institutional logics (Thornton \& Ocasio, 2008), this research would be complemented by studies on interactions between organizational actors and regulatory officials as well as microfoundational work (Barney \& Felin, 2013; Braguinsky \& Hounshell, 2016; Dunbar \& Ahlstrom, 1995).

\section{Conclusion}

How does the organizational size of a firm impact its experience of institutional complexity, and affect its subsequent adaptation to the changes engendered by economic globalization? Some studies seem to suggest that larger firms are better placed to weather the commodification caused by intruding institutional logics. We show, however, that small, rather than large firms, are in fact better suited to adapt to institutional change, so long as they can carve out a particular niche market for themselves. Our comparative case study showed that the small firm performed better, because it did not get caught in the trap of merely mimicking MNCs and playing catchup like the large local firms. In sum, if this article had one key message, it would be that if a firm persists in providing service in a market space which is extremely commoditized, and in which it suffers a legitimacy deficit, it will clearly suffer. Therefore, the recommendation would be to bite the bullet now and undergo painful restructuring. Instead, if a firm is able to carve out its own market niche by doing relatively lucrative work that international competitors are unable to do, it can benefit from its local expertise. That is an interesting feature of professional work, and in a sense conveys hope - that the relationship between the client and the professional cannot be done away with completely, no matter how commoditized the sector might be.

Acknowledgements The authors would like to thank the Editor, David Ahlstrom, and two anonymous reviewers, for their insightful and detailed comments. The authors would also like to thank Marleen Dieleman, Chiu Chi-Yue, and Tan Joo Seng for their invaluable comments on earlier drafts of this article.

Open Access This article is distributed under the terms of the Creative Commons Attribution 4.0 International License (http://creativecommons.org/licenses/by/4.0/), which permits unrestricted use, distribution, and reproduction in any medium, provided you give appropriate credit to the original author(s) and the source, provide a link to the Creative Commons license, and indicate if changes were made. 


\section{References}

Abbott, A. 1988. The systems of professions. An essay on the division of expert labor. Chicago:Chicago University Press.

Agrawal, A., \& Henderson, R. M. 2002. Putting patents in context: Exploring knowledge transfer from MIT. Management Science, 48(1): 44-60.

Ahlstrom, D. 2010. Publishing in the Asia Pacific Journal of Management. Asia Pacific Journal of Management, 27(1): 1-8.

Ahlstrom, D., Bruton, G. D., \& Yeh, K. S. 2008. Private firms in China: Building legitimacy in an emerging economy. Journal of World Business, 43(4): 385-399.

Ahlstrom, D., Bruton, G. D., \& Zhao, L. 2013. Turning good research into good publications. Nankai Business Review International, 4(2): 92-106.

Ahmadjian, C. L., \& Okumura, A. 2006. Corporate governance in Japan. In C. A. Mallin (Ed.). Handbook on international corporate governance: 130-147. Cheltenham: Edward Elgar.

Asian Legal Business. 2015. Asia's Top 50 Largest Law Firms 2015. http://www.legalbusinessonline. com/reports/asias-top-50-largest-law-firms-2015, Accessed July 10, 2017.

Banalieva, E. R., Cuervo-Cazurra, A., \& Sarathy, R. 2018. Dynamics of pro-market institutions and firm performance. Journal of International Business Studies, 49: 858-880.

Barney, J., \& Felin, T. 2013. What are microfoundations? Academy of Management Perspectives, 27(2): 138-155.

Battilana, J., \& Dorado, S. 2010. Building sustainable hybrid organizations: The case of commercial microfinance organizations. Academy of Management Journal, 54: 1419-1440.

Battilana, J., \& Lee, M. 2014. Advancing research on hybrid organizing-Insights from the study of social enterprises. Academy of Management Annals, 8: 397-441.

Besharov, M. L., \& Smith, W. K. 2014. Multiple institutional logics in organizations: Explaining their varied nature and implications. Academy of Management Review, 39: 364-381.

Blume, A. 2010. Your virtual success: Finding profitability in an online world. Pompton Plains: Career Press.

Braguinsky, S., \& Hounshell, D. A. 2016. History and nanoeconomics in strategy and industry evolution research: Lessons from the Meiji-era Japanese cotton spinning industry. Strategic Management Journal, 37(1): 45-65.

Brint, S. 1994. In an age of experts: The changing role of professionals in politics and public life. Princeton: Princeton University Press.

Broomhall, E. 2013. Open season-The influx of global firms making their mark in Singapore. http://www. legalweek.com/sites/legalweek/2013/05/23/open-season-the-influx-of-global-firms-making-theirmark-insingapore, Accessed March 10, 2015.

Budhwar, P., Pereira, V., Mellahi, K., \& Singh, S. K. 2018. The state of HRM in the Middle East: Challenges and future research agenda. Asia Pacific Journal of Management. https://doi.org/10.1007/s10490-0189587-7.

Chan, J. W. T. 2009. Liberalisation of the Singapore legal sector. Paper presented at the 10 General Assembly of ASEAN Law Association. http://www.aseanlawassociation.org/10GAdocs/Singapore3.pdf, Accessed April 13, 2018.

Chang, S. J. (Ed.) 2005. Business groups in Asia. Oxford:Oxford University Press.

Covaleski, M. A., Dirsmith, M. W., \& Rittenberg, L. 2003. Jurisdictional disputes over professional work: The institutionalization of the global knowledge expert. Accounting, Organizations and Society, 28(4): 323-355.

D’Aunno, T., Succi, M., \& Alexander, J. A. 2000. The role of institutional and market forces in divergent organizational change. Administrative Science Quarterly, 45: 679-703.

Dawar, N., \& Frost, T. 1999. Competing with giants: Survival strategies for local companies in emerging markets. Harvard Business Review, 77(2): 119-129.

DiMaggio, P. J. 1983. The Iron Cage revisited: Institutional isomorphism and collective reality in organizational fields. American Sociology Review, 48(2): 147-160.

DiMaggio, P. J. 1991. Constructing an organizational field as a professional project: US art museums, 19201940. In W. W. Powell, \& P. J. DiMaggio (Eds.). The new institutionalism in organizational analysis: 267-292. Chicago: University of Chicago Press.

Dunbar, R. L. M., \& Ahlstrom, D. 1995. Seeking the institutional balance of power: Avoiding the power of a balanced view. Academy of Management Review, 20(1): 171-192.

Eisenhardt, K. M. 1989. Building theories from case study research. Academy of Management Review, 14: $532-550$.

Faulconbridge, J., \& Muzio, D. 2016. Global professional service firms and the challenge of institutional complexity: 'Field relocation' as a response strategy. Journal of Management Studies, 53(1): 89-124. 
Flood, J. 1996. Megalawyering in the global order: The cultural, social, economic transformation of global legal practice. International Journal of the Legal Professions, 3: 169-214.

Friedland, R., \& Alford, R. R. 1991. Bringing society back in: Symbols, practices, and institutional contradictions. In W. W. Powell, \& P. J. DiMaggio (Eds.). The new institutionalism in organizational analysis: 232-263. Chicago: University of Chicago Press.

Goodrick, E., \& Reay, T. 2011. Constellations of institutional logics: Changes in the professional work of pharmacists. Work and Occupations, 38(3): 372-416.

Goodrick, E., \& Salancik, G. R. 1996. Organizational discretion in responding to institutional practices: Hospitals and cesarean births. Administrative Science Quarterly, 41: 1-28.

Greenwood, R., Raynard, M., Kodeih, F., Micelotta, E. R., \& Lounsbury, M. 2011. Institutional complexity and organizational responses. Academy of Management Annals, 5(1): 317-371.

Greenwood, R., \& Suddaby, R. 2006. Institutional entrepreneurship in mature fields: The Big Five accounting firms. Academy of Management Journal, 49(1): 27-48.

Guo, H., Su, Z., \& Ahlstrom, D. 2016. Business model innovation: The effects of exploratory orientation, opportunity recognition, and entrepreneurial bricolage in an emerging economy. Asia Pacific Journal of Management, 33(2): 533-549.

Hannan, M., \& Freeman, J. 1989. Organizational ecology. Cambridge:Harvard University Press.

Haveman, H. A., \& Rao, H. 1997. Structuring a theory of moral sentiments: Institutional and organizational coevolution in the early thrift industry. American Journal of Sociology, 102: 1606-1651.

Hazard, G. C., \& Dondi, A. 2004. Legal ethics: A comparative study. Stanford:Stanford University Press.

Hirsch, P. M. 1986. From ambushes to golden parachutes: Corporate takeovers as an instance of cultural framing and institutional integration. American Journal of Sociology, 91: 800-837.

Ingram, P. 1998. Changing the rules: Interests, organizations, and institutional change in the US hospitality industry. In M. C. Brinton, \& V. Nee (Eds.). The new institutionalism in sociology: 258-276. Stanford: Stanford University Press.

Jamali, D. 2010. MNCs and international accountability standards through an institutional lens: Evidence of symbolic conformity or decoupling. Journal of Business Ethics, 95(4): 617-640.

Jones, E. 1995. True and fair: A history of Price Waterhouse. London:Hamish Hamilton.

Kostova, T., Roth, K., \& Dacin, T. M. 2008. Institutional theory in the study of multinational corporations: A critique and new directions. Academy of Management Review, 33(4): 994-1006.

Kraatz, M., \& Block, E. 2008. Organizational implications of institutional pluralism. In R. Greenwood, C. Oliver, R. Suddaby, \& K. Sahlin-Andersson (Eds.). The Sage handbook of organizational institutionalism: 243-275. Thousand Oaks: Sage.

Kraatz, M. S., \& Moore, J. H. 2002. Executive migration and institutional change. Academy of Management Journal, 45: 120-143.

Kraatz, M. S., \& Zajac, E. J. 1996. Exploring the limits of the new institutionalism: The causes and consequences of illegitimate organizational change. American Sociological Review, 61: 812-836.

Kumaraswamy, A., Mudambi, R., Saranga, H., \& Tripathy, A. 2012. Catch up strategies in the Indian auto components industry: Domestic firms' responses to market liberalization. Journal of International Business Studies, 43: 368-395.

Kuttner, R. 1997. Everything for sale: The virtues and limits of markets. New York:Knopf.

Landis, J. R., \& Koch, G. G. 1977. The measurement of observer agreement for categorical data. Biometrics, 33(1): 159-174.

Langlois, R. N. 1998. Personal capitalism as charismatic authority: The organizational economics of a Weberian concept. Industrial and Corporate Change, 7: 195-214.

Law Society. 2017. Statistics. http://www.lawsociety.org.sg/AboutUs/GeneralStatistics.aspx, Accessed December 10, 2017.

Leblebici, H., Salancik, G., Copay, A., \& King, T. 1991. Institutional change and the transformation of the US radio broadcasting industry. Administrative Science Quarterly, 36(3): 333-363.

Lee, E. B., \& Ong, A. C. L. 2013. The challenges in going regional. Business Times: May 16.

López-Duarte, C., Vidal-Suárez, M. M., \& González-Díaz, B. 2018. The early adulthood of the Asia Pacific Journal of Management: A literature review 2005-2014. Asia Pacific Journal of Management, 35(2): 313-345.

Lounsbury, M., Ventresca, M., \& Hirsch, P. M. 2003. Social movements, field frames, and industry emergence: A cultural-political perspective on US recycling. Socio-Economic Review, 1(1): 71-104.

Miles, M. B., Huberman, A. M., \& Saldana, J. 2014. Qualitative data analysis: A methods sourcebook. Beverly Hills: Sage.

Ministry of Law. 2013. Press Release-Award of the second round of Qualifying Foreign Law Practice licenses. http://www.mlaw.gov.sg/news/press-releases/award-of-secondround-qflp-licences.html, Accessed June 2, 2013. 
Ministry of Law. 2017. Statistics. https://www.mlaw.gov.sg, Accessed September 10, 2017.

Murray, F. 2010. The OncoMouse that roared: Hybrid exchange strategies as a source of distinction at the boundary of overlapping institutions. American Journal of Sociology, 116(2): 348-388.

Oakes, L. S., Townley, B., \& Cooper, D. 1998. Business planning as pedagogy: Language and control in a changing institutional field. Administrative Science Quarterly, 43: 257-292.

Ocasio, W., \& Kim, H. 1999. The circulation of corporate control: Selection of functional backgrounds of new CEOs in large US manufacturing firms, 1981-1992. Administrative Science Quarterly, 44(3): 532-562.

Pache, A., \& Santos, F. 2010. Inside the hybrid organization: An organizational level view of responses to conflicting institutional demands. Working paper no. 57, ESSEC Business School, ESSEC University, Cergy, France.

Palmer, D., \& Barber, M. 2001. Challengers, elites and owning families: A social class theory of corporate acquisitions in the 1960s. Administrative Science Quarterly, 46(1): 87-120.

Peng, M. W., Ahlstrom, D., Carraher, S. M., \& Shi, W. S. 2017. An institution-based view of global IPR history. Journal of International Business Studies, 48(7): 893-907.

Pettigrew, A. 1990. Longitudinal field research on change: Theory and practice. Organization Science, 1(3): 267-292.

Previts, G. J. 1985. The scope of CPA services: A study of the development of the concept of independence and the profession's role in society. New York:Wiley.

Rao, H., Monin, P., \& Durand, R. 2003. Institutional change in Toque Ville: Nouvelle cuisine as an identity movement in French gastronomy. American Journal of Sociology, 108: 795-843.

Rawat, S., \& Meena, S. 2014. Publish or perish: Where are we heading? Journal of Research in Medical Sciences, 19(2): 87-89.

Reay, T., \& Hinings, C. R. 2009. Managing the rivalry of competing institutional logics. Organization Studies, 30: 629-652.

Schneiberg, M. 2002. Organizational heterogeneity and the production of new forms: Politics, social movements and mutual companies in American fire insurance, 1900-1930. Research in the Sociology of Organizations, 19: 39-89.

Schweizer, L. 2005. Organizational integration of acquired biotechnology companies in pharmaceutical companies: The need for a hybrid approach. Academy of Management Journal, 48: 1051-1074.

Scott, W. R. 2008. Lords of the dance: Professionals as institutional agents. Organization Studies, 29(2): 219-238.

Shapiro, J. M., Ozanne, J. L., \& Saatcioglu, B. 2008. An interpretive examination of the development of cultural sensitivity in international business. Journal of International Business Studies, 39(1): 71-87.

Smets, M., Morris, T., \& Greenwood, R. 2012. From practice to field: A multilevel model of practice-driven institutional change. Academy of Management Journal, 55: 877-904.

Stark, D. 1996. Recombinant property in Eastern European capitalism. American Journal of Sociology, 101: 993-1027.

Strauss, A., \& Corbin, J. 1990. Basics of qualitative research: Grounded theory procedures and techniques. Newbury Park:Sage.

Stryker, R. 2000. Legitimacy processes as institutional politics: Implications for theory and research in the sociology of organizations. Organizational Politics: Research in the Sociology of Organizations, 17: 179-223.

Suddaby, R., \& Greenwood, R. 2005. Rhetorical strategies of legitimacy. Administrative Science Quarterly, 50(1): 35-67.

Tan, H. 2017. Making impact through industry-focused research: An Asia Pacific perspective. Asia Pacific Journal of Management, 34(3): 487-503.

Tan, J., \& Wang, L. 2011. MNC strategic responses to ethical pressure: An institutional logic perspective. Journal of Business Ethics, 98(3): 373-390.

The American Lawyer. 2015. The American Lawyer's 2015 Global 100 Ranking. http:/www.americanlawyer. com, Accessed September 15, 2017.

The American Lawyer. 2017. The American Lawyer's 2017 Am Law 200 Ranking. http://www.americanlawyer. com/law-firm-profiles-result?firmname=Latham+\%26+Watkins, Accessed September 15, 2017.

Thornton, P. H. 2004. Markets from culture: Institutional logics and organizational decisions in higher education publishing. Stanford:Stanford University Press.

Thornton, P. H., Jones, C., \& Kury, K. 2005. Institutional logics and institutional change in organizations: Transformation in accounting, architecture, and publishing. Research in the Sociology of Organizations, 23: $125-170$.

Thornton, P. H., \& Ocasio, W. 1999. Institutional logics and the historical contingency of power in organizations: Executive succession in the higher education publishing industry 1958-1990. American Journal of Sociology, 105(3): 801-843.

Thornton, P. H., \& Ocasio, W. 2008. Institutional logics. In R. Greenwood, C. Oliver, K. Sahlin, \& R. Suddaby (Eds.). The Sage handbook of organizational institutionalism: 99-129. London: Sage. 
Tsui-Auch, L. S., \& Moellering, G. 2010. Wary managers: Vulnerability and the development of trust in foreign enterprises in China. Journal of International Business Studies, 41(6): 1056-1073.

Tsui-Auch, L. S., Yoshikawa, T., \& Yang, J. J. 2015. Institutional change versus resilience: A study of incorporation of independent directors in Singapore banks. Asian Business and Management, 14(2): 91-115.

Wang, L. C., Ahlstrom, D., Nair, A., \& Hang, R. Z. 2008. Creating globally competitive and innovative products: China's next Olympic challenge. SAM Advanced Management Journal, 73(3): 4-15.

Wu, J., \& Pangarkar, N. 2006. Rising to the global challenge: Strategies for firms in emerging markets. Long Range Planning, 39(3): 295-313.

Yin, R. 1981. The case study crisis: Some answers. Administrative Science Quarterly, 26(1): 58-65.

Yin, R. K. 2017. Case study research and applications: Design and methods. Thousand Oaks:Sage.

Yoffie, D. B., \& Cusumano, M. A. 1999. Judo strategy: The competitive dynamics of Internet time. Harvard Business Review, 77(1): 70-81.

Yoshikawa, T., Tsui-Auch, L. S., \& McGuire, J. 2007. Corporate governance reform as institutional innovation: The case of Japan. Organization Science, 18: 973-988.

Young, M. N., Tsai, T., Wang, X., Liu, S., \& Ahlstrom, D. 2014. Strategy in emerging economies and the theory of the firm. Asia Pacific Journal of Management, 31(2): 331-354.

Publisher's note Springer Nature remains neutral with regard to jurisdictional claims in published maps and institutional affiliations.

Dawn Y. Chow ( $\mathrm{PhD}$, Nanyang Technological University) is a lecturer (assistant professor) at the School of Business, Singapore University of Social Sciences. Prior to her doctoral studies, she obtained her MBA from the University of Warwick, UK. Her current research focuses on political ideology (left or right) in M\&A choice of targets, institutional logics, institutional work, attachment to home country, as well as the coevolution of MNEs and their institutional environment. Dr. Chow has a conditionally accepted manuscript at a top I.M/I.B journal, as well as other publications which are currently in the peer review process at top journals. She has also published in conference proceedings such as those of the Academy of Management and the Strategic Management Society, as well as book chapters in the Wiley Encyclopedia of Management and in the World Scientific Publishing book on Catalysts of Change.

Lai Si Tsui-Auch (PhD, Michigan State University) is Associate Professor at the Nanyang Business School, Nanyang Technological University of Singapore. Prior to joining NTU, she worked as research scientist at the Technological University of Berlin and Wissenschaft Zentrum Berlin für Sozialforchung (WZB), Germany. Her current research focuses on legitimacy management by multinational corporations and politicallyconnected globalizing firms. One of her conference papers was the Winner of the Carolyn Dexter Best International Paper Award of the Academy of Management Meeting in 2007, and her Organization Studies 2005 paper won a Citation of Excellence Award for 2006 by Emerald Management Reviews. Her research has been published in Organization Science, Journal of International Business Studies, Organization Studies, Journal of Management Studies, International Sociology, International Journal of Urban and Regional Research, etc.

\section{Affiliations}

\section{Dawn Y. Chow ${ }^{1} \cdot$ Lai Si Tsui-Auch ${ }^{2}$}

1 School of Business, Singapore University of Social Sciences, 461 Clementi Road, Singapore 599491, Republic of Singapore

2 Business School, Nanyang Technological University, 50 Nanyang Ave, Singapore 639798, Singapore 